\title{
Marker-trait association study for root-related traits in chickpea (Cicer arietinum L.)
}

\author{
Zahra SHEKARI $^{1}$, Zahra TAHMASEBI ${ }^{1,2}$, Homayoun KANOUNI ${ }^{3}$, Ali Asherf MEHRABI ${ }^{1}$
}

Received April 11, 2021; accepted June 16, 2021. Delo je prispelo 11. aprila 2021, sprejeto 16. junija 2021

\begin{abstract}
Marker-trait association study for root-related traits in chickpea (Cicer arietinum L.)

Abstract: Root structure modification can improve important agronomic traits including yield, drought tolerance and nutrient deficiency resistance. The aim of the present study was to investigate the diversity of root traits and to find simple sequence repeat (SSR) markers linked to root traits in chickpea (Cicer arietinum L.). This research was performed using 39 diverse accessions of chickpea. The results showed that there is significant variation in root traits among chickpea genotypes. A total of 26 alleles were detected 26 polymorphic bands were produced by 10 SSR markers in the eight linkage groups (LG). The results indicated that there is substantial variability present in chickpea germplasm for root traits. By analyzing the population structure, four subpopulations were identified. PsAS2, AF016458, 16549 and 19075 SSR markers on LG1, LG3, LG2 and LG1 linkage group respectively were associated with root traits. The research findings provide valuable information for improving root traits for chickpea breeders.
\end{abstract}

Key words: linkage groups; drought tolerance; population structure; SSR markers; subpopulations; variation
Raziskava povezave genskih označevalcev in lastnosti korenin pri čičerki (Cicer arietinum L.)

Izvleček: Sprememba zgradbe korenin lahko izboljša pomembne agronomske lastnosti vključno s pridelkom, strpnost za sušo in odpornost na pomanjkanje hranil. Namen raziskave je bil preučiti raznolikost lastnosti korenin in najti enostavne označevalce ponavljajočih se zaporedij (SSR) povezanih z lastnostmi korenin pri čičerki (Cicer arietinum L.). Raziskava je bila opravljena na 39 različnih akcesijah čičerke. Rezultati so pokazali, da obstaja značilna spremenljivost $\mathrm{v}$ lastnostih korenin med genotipi čičerke. Celokupno je bilo ugotovljeno 26 alelov. 10 SSR označevalcev je dalo 26 polimorfnih prog v osmih povezanih skupinah (LG). Izsledki so pokazali, da obstaja $\mathrm{v}$ dednem materialu čičerke znatna variabilnost $\mathrm{v}$ lastnostih korenin. $\mathrm{Z}$ analizo zgradbe populacije so bile ugotovljene štiri podpopulacije. PsAS2, AF016458, 16549 in 19075 SSR označevalci v LG1, LG3, LG2 in LG1 povezanih skupinah so bili povezani $\mathrm{z}$ lastnostmi korenin. Ugotovitve raziskave prispevajo žlahtniteljem čičerke pomembne informacije za izboljšanje lastnosti korenin.

Ključne besede: povezane skupine; toleranca na sušo; zgradba populacije; SSR označevalci; podpopulacije; variabilnost

1 Agronomy and Plant Breeding Department, Agricultural College, Ilam University, Ilam, Iran

2 Corresponding author, e-mail: z.tahmasebi@ilam.ac.ir

3 Research Associate, Field and Horticultural Crops Reseach Unit, Agricultural and Natural Resources Research and Education Center of Kurdistan, Agricultural Research, Education and Extension Organization, Iran 


\section{INTRODUCTION}

Chickpea (Cicer arietinum L., $2 \mathrm{n}=16$ ) as a third major legume in the world widely used for food and fodder. Numerous biotic and abiotic stresses affect the production and yield of chickpea of which drought is one of the most important abiotic constraints. Drought causes heavy production losses, about 45-50 \% in chickpea (Ahmad et al., 2005).

For drought management, genetic improvement over crop options for better adaptation to drought can be a sustainable and low-cost solution. But, it is very difficult to understand the maintenance of potential yield under drought stress, due to the different mechanisms used by plants to maintain growth under limited water resource, (Tuberosa \& Salvi, 2006). The major challenges in identifying drought tolerance genotypes is drought interaction with the environment and its quantitative inheritance (Varshney et al., 2014).

Root structure modification can improve important agronomic traits including yield, drought tolerance and nutrient deficiency resistance (Tuberosa et al., 2002; Beebe et al., 2006; Ghanem et al., 2011). Despite, approximately small populations and inaccurate phenotyping cause it difficult to make large scale use of root genetic information in plant breeding (de Dorlodot et al., 2007). From now, correct phenotyping and characterization of root traits is necessary for translating novel physiological and genetic progresses into a conception of the role of root systems in increasing yield and productivity (especially in dry environments). The effect of diverse root features on drought tolerance were found to be high under final drought stress condition, mainly in environment where plant only confide in the stored soil water (Ludlow \& Muchow, 1990; Kashiwagi et al., 2006; Passioura, 2006; Wasson et al., 2014). For example, Kirkegaard et al. (2007) indicated using root traits and soil moisture assessments in the field, that a $30 \mathrm{~cm}$ enhance in root depth increased the uptake of $10 \mathrm{~mm}$ more underground soil moisture and thus increased the yield by $0.5 \mathrm{t} \mathrm{ha}^{-1}$ grain yield. it also was demonstrated that Large root system effect on shoot biomass production and harvest index (HI) under terminal drought stress (Kashiwagi et al., 2006; ZamanAllah et al., 2011). Although plant breeders are aware of the worth of the root system offering, but due to the low heritability of root traits, high variation in expression in different soils and soil moisture environments, and the difficulty of measuring these traits in the field has been less pay attention to these traits selection (Tuberosa et al., 2002; Malamy, 2005; Gaur et al., 2008).

Genetic diversity has been investigated using diverse types of DNA markers, including SSR in chickpea
(Sefera et al., 2011; Keneni et al., 2012; Ghaffari et al., 2014; Hajibarat et al., 2015). DNA markers have been found for many agronomic traits (Thudi et al., 2014a).

Majority of the breeding attempts made in chickpea have been, and are being, focused on improving yield, resistance to diseases like Ascochyta blight and Fusarium wilt (Varshney et al., 2014a) and on tolerance to various abiotic stresses (such as drought (Varshney et. al., 2014; Jaganathan et al., 2015), cold (Mugabe et. al., 2019) and heat tolerance (Jha et al., 2018)). However even with the value of root traits and their critical roles in drought and heat adaptation in chickpea ( Maphosa et. al., 2020), their genetic control has been less studied. Consequential associations between markers and quantitative traits led to the identification of locus significantly associated with drought tolerance. The root phenotyping problems has reduced the identity of root trait genomic locus in chickpea thus the aim of this research was to identify of the SSR markers associated with root-related traits in a various chickpea germplasm.

\section{MATERIAL AND METHODS}

Plant material contains 39 chickpea genotypes, including accessions from ICARDA (International Center for Agricultural Research in the Dry Areas) chickpea germplasm (Table 1). These entries were selected based on the results of previous drought tolerance trials in Kabuli type chickpea genotypes.

\subsection{GENOTYPING}

\subsubsection{DNA extraction and SSR primers, PCR and aga- rose gel electrophoresis}

Genomic DNA was extracted from young leaflets of chickpea genotypes plant leaves (4 plants of each genotypes) using a CTAB method according Doyle and Doyle (1987) with a slight modification. On the basis of their locations on the eight linkage groups (LGs) of the integrated genetic linkage map of chickpea (Cicer arietinum L.), altogether 10 SSR markers were select (Sefera et al., 2011) (Table 2). PCR was carried out in a $14 \mu \mathrm{l}$ reaction mixture that contain $100 \mathrm{ng}$ of DNA, 100 pmol of each primer (forward and reverse), $7 \mu$ of CinnaGen PCR master mix, $2 \mathrm{X}\left(0.08\right.$ units $\mu \mathrm{l}^{-1}$ Taq DNA polymerase in reaction buffer, $3 \mathrm{mmol} \mathrm{MgCl}_{2}$, and 1.6 mmol dNTPs). The amplifications were performed with a Thermal Cycler (Applied Bio Rad, Foster City, CA, 
USA), with an initial denaturation at $94{ }^{\circ} \mathrm{C}$ for $240 \mathrm{sec}$ that was followed by 10 cycles of: at $94{ }^{\circ} \mathrm{C}$ for $30 \mathrm{~s}, 45 \mathrm{~s}$ at annealing temperature (Ta) (Table 2), $120 \mathrm{~s}$ at $72{ }^{\circ} \mathrm{C}$, and then was followed by 25 cycles of: 30 s at $94{ }^{\circ} \mathrm{C}, 45$ $\mathrm{s}$ at Ta, $120 \mathrm{~s}$ at $72{ }^{\circ} \mathrm{C}$ and a final extension step at $72{ }^{\circ} \mathrm{C}$ for $420 \mathrm{~s}$ In $2.5 \%$ agarose gel by $1 \mathrm{X}$ TBE running buffer, amplified fragments were resolved and quantity one software (Bio-Rad, CA 94547, USA) analyzed images.

Table 1: The list of genotypes used in the present study

\begin{tabular}{|c|c|c|}
\hline NO. & Genotype Name & Pedigree \\
\hline 1 & FLIP97-706C & X04TH62/X03TH-130XFLIP97-116 \\
\hline 2 & FLIP03-77C & X04TH65/X03TH-133XFLIP96-154 \\
\hline 3 & FLIP03-130C & X04TH65/X03TH-133XFLIP96-154 \\
\hline 4 & FLIP06-158C & X04TH65/X03TH-133XFLIP96-154 \\
\hline 5 & FLIP07-19C & X04TH66/X03TH-134XFLIP97-116 \\
\hline 6 & FLIP07-20C & X04TH66/X03TH-134XFLIP97-116 \\
\hline 7 & FLIP07-22C & X04TH66/X03TH-134XFLIP97-116 \\
\hline 8 & FLIP07-28C & X04TH67/X03TH-135XFLIP99-34 \\
\hline 9 & FLIP07-31C & X04TH67/X03TH-135XFLIP99-34 \\
\hline 10 & FLIP07-44C & X04TH76/X03TH-144XFLIP97-116 \\
\hline 11 & FLIP07-239C & X04TH77/X03TH-145XFLIP99-34 \\
\hline 12 & FLIP07-261C & X04TH79/X03TH-147XFLIP96-154 \\
\hline 13 & FLIP07-280C & X04TH110/X03TH-178XFLIP97-116 \\
\hline 14 & FLIP08-46C & X04TH110/X03TH-178XFLIP97-116 \\
\hline 15 & FLIP08-200C & X04TH114/X03TH-182XFLIP97-116 \\
\hline 16 & FLIP09-70C & X04TH115/X03TH-183XFLIP99-34 \\
\hline 17 & FLIP09-81C & X04TH117/X03TH-185XFLIP96-154 \\
\hline 18 & FLIP09-85C & X04TH123/FLIP97-205XFLIP97-116 \\
\hline 19 & FLIP09-90C & X04TH124/FLIP97-229XFLIP99-34 \\
\hline 20 & FLIP09-98C & X04TH126/FLIP98-229XFLIP96-154 \\
\hline 21 & FLIP09-148C & X04TH129/FLIP98-233XFLIP99-48 \\
\hline 22 & FLIP09-149C & X05TH7/X04TH-126XFLIP01-18 \\
\hline 23 & FLIP09-189C & X05TH106/FLIP97-131XFLIP00-14 \\
\hline 24 & FLIP09-191C & X05TH106/FLIP97-131XFLIP00-14 \\
\hline 25 & FLIP09-192C & X05TH106/FLIP97-131XFLIP00-14 \\
\hline 26 & FLIP09-194C & X05TH106/FLIP97-131XFLIP00-14 \\
\hline 27 & FLIP09-214C & X05TH131/FLIP97-118XFLIP00-17 \\
\hline 28 & FLIP09-216C & X05TH152/FLIP98-107XUC27 \\
\hline 29 & FLIP09-218C & X04TH31/X03TH-31XFLIP97-116 \\
\hline 30 & FLIP09-219C & X06TH100/FLIP02-47XFLIP98-230 \\
\hline 31 & ILC482 & ILC482 \\
\hline 32 & FLIP 82-150C & X79TH101/ILC 523 X ILC 183 \\
\hline 33 & FLIP88-85C & X85 TH143/ILC 629 x FLIP 82-144C \\
\hline 34 & FLIP93-93C & X89TH258/ (FLIP 85-122CXFLIP 82-150C)/FLIP 86-77C \\
\hline 35 & FLIP07-180C & X04TH12/X03TH-12XFLIP99-48 \\
\hline 36 & FLIP09-88C & X04TH40/X03TH-40XFLIP99-34 \\
\hline 37 & FLIP09-115C & X04TH50/X03TH-50XFLIP99-34 \\
\hline 38 & FLIP09-337C & X04TH53/X03TH-53XFLIP97-116 \\
\hline 39 & FLIP09-386C & Х04TH59/X03TH-59XFLIP99-48 \\
\hline
\end{tabular}


Table 2: The list of genotypes used in the present study

\begin{tabular}{|c|c|c|c|c|}
\hline NO. & Marker name & Primer sequences $\left(5^{\prime}-3^{\prime}\right)$ & Linkage Group & $\begin{array}{l}\text { Annealing temperature } \\
\left({ }^{\circ} \mathrm{C}\right)\end{array}$ \\
\hline 1 & 19075 & $\begin{array}{l}\text { F:CACGAGTACAACATGGAGTGAAG R: } \\
\text { CAAGCTCAACCTCCTCATACC }\end{array}$ & LG1 & 57.75 \\
\hline 2 & 18363 & $\begin{array}{l}\text { F:CATGCATGGAGTTGGAAGAG R: } \\
\text { GTCCCAAAATGCAGCCAATA }\end{array}$ & LG3 & 55.6 \\
\hline 3 & 16549 & $\begin{array}{l}\text { F:CAATGAGATGCTGGCGATAA R: } \\
\text { GTTCGGTGTTGTGGGTTTTT }\end{array}$ & LG2 & 55.7 \\
\hline 4 & $\mathrm{C} 24$ & $\begin{array}{l}\text { F:GCTACTGGAGGAGGCTTTCA R: } \\
\text { GCCTTCTACACAACGGCTTC }\end{array}$ & LG4 & 58.2 \\
\hline 5 & PsAS2 & $\begin{array}{l}\text { F: CTAATCACACGTTTAGGACCGG R: } \\
\text { CGAAATCCAAACCGAACCTAATCC }\end{array}$ & LG1 & 58.9 \\
\hline 6 & PSAB60 & $\begin{array}{l}\text { F:AATTAATGCCAATCCTAAGGTATT R: } \\
\text { GGTTGCACTATTTTCGTTCTC }\end{array}$ & LG6 & 53.95 \\
\hline 7 & PD23 & $\begin{array}{l}\text { F:ATGGTTGTCCCAGGATAGATAAR: } \\
\text { GAAAACATTGGAGAGTGGAGTA }\end{array}$ & LG 5 & 54.9 \\
\hline 8 & PSAD147 & $\begin{array}{l}\text { F: AGCCCAAGTTTCTTCTGAATCC R: } \\
\text { GAAAACATTGGAGAGTGGAGTA }\end{array}$ & LG7 & 57.55 \\
\hline 9 & 17605 & $\begin{array}{l}\text { F:CGCCCTTCATCATCATCTTC R: } \\
\text { AAATTCGCAGAGCGTTTGTTAC }\end{array}$ & LG 8 & 57.35 \\
\hline 10 & AF016458 & $\begin{array}{l}\text { F:CGCCCTTCATCATCATCTTC R: } \\
\text { CGAATCTTGGCCATGAGAGTTGC }\end{array}$ & LG 3 & 57 \\
\hline
\end{tabular}

\subsection{PHENOTYPING}

\subsubsection{Root sample extraction and processing}

The experiment was conducted in Glasshouse at Ilam university. The average daily temperature was $25 / 16{ }^{\circ} \mathrm{C}$ (day/night), and the humidity was $70 \%$. Experiment was carried out in completely randomized design (CRD) with four replications. The seeds of each genotype were sown in split drain pipes (SDP) with 60 $\mathrm{cm}$ height and $10 \mathrm{~cm}$ diameter. The soil used in SDP was a mixture of sand and Jons Innes No-2 (1:1 ratio). Each SDP was put together with a single plant. The plants were harvested 30 days after germination. Plants were harvested on 35 day after germination based on taproot length increments for the growth period (Chen et al., 2017).

\subsubsection{Root-related traits}

Chickpea root samples were taken to record root traits. Using a water shower, the soil was separated from the roots and then the fresh mass of the roots was measured. Then, by floating the root samples in water in a tray, organic debris and weed roots were removed manually from chickpea roots. The fresh soil and roots were thereupon dried in an oven at $65{ }^{\circ} \mathrm{C}$ for 72 hours and the percentage of soil and root moisture was obtained. The root characteristics are showed in Table 3.

\subsection{STATISTICAL ANALYSIS}

Analysis of variance was performed with the SAS 9.2 software to evaluate the factor "GENOTYPE". The genotype means were compared by a Duncan's multiple range post hoc test and used for the association analyses.

\subsection{ASSOCIATION ANALYSES}

The polymorphism information content (PIC) value was calculated using $P I C=1-\Sigma\left(P_{i j}\right)^{2}$ (Where Pij is the frequency of $j$ th allele in ith primer and summation extends over ' $n$ ' patterns) (Nei , 1973) for each primer. PIC describe content of 'gene diversity'.

NTSYSpc 2.02e was used to compute Jaccard similarity coefficients to report genetic relationships among 
the chickpea genotypes. Also using this software and based on genetic distances, cluster analysis was carried out using the unweighted pair-group (UPGMA) method and the dendrograms were drawn (Rohlf, 2000).

The marker-trait association between the SSR markers and each of root related traits tested using TASSEL 4.0. (Bradbury et al., 2007). General linear model (GLM) and mixed linear model (MLM) approaches used for association analysis. Covariates in
GLM and MLM analyses were the corresponding $Q$ values. Manhattan plots present association between a SSR marker and phenotypic trait that was significant at $p \leq 0.05$. STRUCTURE version 2.3.4 used for determine the population structure of the 39 accessions using the Bayesian clustering method (Pritchard et al., 2000). The STRUCTURE analysis separated the population based on $\Delta K$ method (Evanno et al., 2005).

Table 3: The root related trait measured in the present study

\begin{tabular}{|c|c|c|c|c|}
\hline No. & Trait & Formula & Unit of measurement & References \\
\hline 1 & Root length (RL) & $\begin{array}{l}\text { Total RL of each sample was measured } \\
\text { using a ruler. }\end{array}$ & $\mathrm{cm}$ & - \\
\hline 2 & Root fresh mass (RFM) & $\begin{array}{l}\text { The fresh weight of the roots was measured } \\
\text { with a digital scale to the nearest thousandth }\end{array}$ & g & - \\
\hline 3 & Root dry mass (RDM) & $\begin{array}{l}\text { The roots were kept for oven drying at } 70{ }^{\circ} \mathrm{C} \\
\text { for } 72 \mathrm{~h} \text { (to constant mass) then was estimated. }\end{array}$ & g & Ramamoorthy et al., 2017 \\
\hline 4 & $\begin{array}{l}\text { Dry mass of } \\
\text { plant shoots (SDM) }\end{array}$ & $\begin{array}{l}\text { The shoots were kept for oven drying at } 70{ }^{\circ} \mathrm{C} \\
\text { for } 72 \mathrm{~h} \text { (to constant mass) then SDW was estimated }\end{array}$ & g & Ramamoorthy et al., 2017 \\
\hline 5 & Root volume (RV) & $R V=B-C$ & $\mathrm{~cm}^{3}$ & - \\
\hline 6 & Root area (RA) & $R A=2 \times S Q R T\langle R V \times 3.14 \times R L\rangle$ & $\mathrm{cm}^{2}$ & Akhavan et al., 2012 \\
\hline 7 & Root fineness (RF) & $R F=\frac{R L}{R V}$ & $\begin{array}{l}\mathrm{cm} \text { root } / \text { root } \\
\text { fresh mass }\end{array}$ & Hajabbasi, 2001 \\
\hline 8 & Root diameter (Rd) & $R d=S Q R T \frac{\langle 4 \times R F W\rangle}{\langle R L \times 3.14\rangle}$ & $\mathrm{cm}$ & Schenk \& Barber, 1979 \\
\hline 9 & root length (SRL) Specific & $S R L=\frac{R L}{R D W}$ & $\begin{array}{l}\mathrm{cm} \text { root length } \\
\mathrm{cm}^{-3} \text { soil volume }\end{array}$ & Mahanta et al., 2014 \\
\hline 10 & $\begin{array}{l}\text { Root water content } \\
\text { (RWC) }\end{array}$ & $R W C=\frac{R F W-R D W}{R D W}$ & g & Lovelli et al., 2012 \\
\hline 11 & $\begin{array}{l}\text { Root length density } \\
\text { (RLD) }\end{array}$ & $R L D=\frac{R L}{S V}$ & $\begin{array}{l}\mathrm{cm} \mathrm{RL} \mathrm{cm}^{-3} \\
\text { soil volume }\end{array}$ & Mahanta et al., 2014 \\
\hline 12 & $\begin{array}{l}\text { Specific root volume } \\
\text { (SRV) }\end{array}$ & $S R V=\frac{R D W}{S V}$ & $\begin{array}{l}\mathrm{g} \mathrm{RDW} \mathrm{cm}^{-3} \\
\text { soil volume) }\end{array}$ & Hasanabadi et al., 2010 \\
\hline 13 & $\begin{array}{l}\text { Root tissue density } \\
\text { (RTD) }\end{array}$ & $R T D=R D W \times R V$ & $\begin{array}{l}\mathrm{g} \mathrm{RDW} \times \mathrm{cm}^{3} \\
\text { soil volume }\end{array}$ & Paula \& Pausas, 2011 \\
\hline 14 & $\begin{array}{l}\text { Root volume density } \\
\text { (RVD) }\end{array}$ & $R V D=\frac{R F W}{S V}$ & $\mathrm{~cm} \mathrm{~m}^{-3}$ & Hajabbasi, 2001 \\
\hline 15 & Root area density (RAD) & $R A D=R L \times R D \times 3.14$ & $\mathrm{~cm}^{2} \mathrm{~cm}^{-3}$ & Akhavan et al., 2012 \\
\hline 16 & Root density (RD) & $R D=\frac{R D W}{R V}$ & $\mathrm{~g} \mathrm{~cm}^{-3}$ & Akhavan et al., 2012 \\
\hline
\end{tabular}

$\mathrm{B}=$ water and root volume, $\mathrm{C}=$ water volume, $\mathrm{SQRT}=$ root square 


\section{RESULTS}

\subsection{ANALYSIS OF ROOT TRAITS DATA}

Root morphological traits differed significantly among genotypes. All of 16 measured root related traits differed significantly among genotypes $(p \leq 0.001)$ (Table 4). The average root length was $50.69 \mathrm{~cm}$ and ranged from 27 to $72 \mathrm{~cm}$ (Table 5). The variation (Coef. Var. ) in RL among genotypes was $20.7 \%$ (Table 5). Root volume (RV) and root fresh mass (RFM) varied significantly among genotypes (Table 5). RV ranged from $3.75 \mathrm{~cm}^{3}$ (FLIP07-28C) to $22 \mathrm{~cm}^{3}$ (FLIP07-31C), with an average root volume of $11.5 \mathrm{~cm}^{3}$. The root fresh mass (RFM) averaged $10.93 \mathrm{~g}$ across all genotypes. RFM varied among genotypes and ranged from $2.69 \mathrm{~g}$ (FLIP07$28 \mathrm{C})$ to $22.52 \mathrm{~g}$ (FLIP09-192C). Root dry mass (RDM) was $0.15 \mathrm{~g}$ (ILC482) to 3.93g (FLIP09-192C) (average $1.33 \mathrm{~g})$. The average leaf dry mass (LDM) was $0.91 \mathrm{~g}$, ranging from $0.17 \mathrm{~g}$ (FLIP07-31C) to $2.28 \mathrm{~g}$ (FLIP09$192 \mathrm{C}$ ), and root fineness (RF) ranged from 2.07 FLIP97-706C to 13 (FLIP88-85C) (mean $4.95 \mathrm{~cm}$ root / root fresh mass). The average specific root length (SRL) was $50.37 \mathrm{~cm}$ and ranged from $15 \mathrm{~cm}$ (FLIP97-706C) to $238.71 \mathrm{~cm}$ (FLIP 82-150C). Root water content (RWC) averaged $8.30 \mathrm{~g}$ across all genotypes. RWC ranged from 2.58 (FLIP07-31C) to 30.88 (FLIP07-20C). The average root tissue density (RTD) ranging from 0.61 (ILC482) to 86.53 (FLIP07-31C) (mean $16.47 \mathrm{~g} \mathrm{RDW} \times \mathrm{cm}^{3}$ soil volume). Root diameter ( $\mathrm{Rd}$ ) ranged from $0.038 \mathrm{~cm}$ (FLIP88-85C) to $0.27 \mathrm{~cm}$ (FLIP09-192C), with an average root volume of $0.12 \mathrm{~cm}$. The average root area (RA) was $83.69 \mathrm{~cm}^{2}$ and ranged from $36.83 \mathrm{~cm}^{2}$ (FLIP07$28 \mathrm{C}$ ) to $127.68 \mathrm{~cm}^{2}$ (FLIP07-31C). The average root density(RD) was $0.52 \mathrm{~g} \mathrm{~cm}^{-3}$ and ranged from $0.29 \mathrm{~g}$ $\mathrm{cm}^{-3}$ (ILC482) to $0.71 \mathrm{~g} \mathrm{~cm}^{-3}$ (FLIP07-31C). Root length density (RLD) ranging from 0.05 (FLIP07-28C) to 0.13 (FLIP07-20C) (mean $0.094 \mathrm{~cm} \mathrm{RL} \mathrm{cm}^{-3}$ soil volume). The average specific root volume (SRV) was 0.0025 $\mathrm{g} \mathrm{RDM} \mathrm{cm} \mathrm{cm}^{-3}$ soil volume and ranged from 0.0028 (ILC482) to $0.0073 \mathrm{~g} \mathrm{RDM} \mathrm{cm}^{-3}$ soil volume (FLIP09192C). Root volume density (RVD) ranged from 0.0050 $\mathrm{cm} \mathrm{m}^{-3}$ (FLIP07-28C) to $0.042 \mathrm{~cm} \mathrm{~m}^{-3}$ (FLIP09-192C), with an average RVD of $0.020 \mathrm{~cm} \mathrm{~m}^{-3}$. Root area density (RAD) averaged across all genotypes $82.14 \mathrm{~cm}^{2} \mathrm{~cm}$ 3. RAD ranged from $30.20 \mathrm{~cm}^{2} \mathrm{~cm}^{-3}$ (FLIP07-28C) to $129.19 \mathrm{~cm}^{2} \mathrm{~cm}^{-3}$ (FLIP09-192C).

\subsection{SSR MARKER SCREENING AND GENETIC DIVERSITY ASSESSMENT}

Using the SSR marker system the genetic diversity of 39 chickpea genotypes analyzed. Detected alleles were 26. 2-3 bands with an average number of 2.6 alleles per locus observed. AF016458، 17605، PSAD147، 19075، 16549 and PD23 had 3 alleles.

All of the amplification products (100\%) showed polymorphism, denoted high variation among chickpea accessions at the DNA level. Size of fragments produced varied from 110 to $150 \mathrm{bp}$ (Table 6). The highest PIC was for primer 16549 and PSAD147 (0.54) and the lowest PIC was for the primer C24 (0.38). Hence, primer 16549 and PSAD147 were effective and useful markers for determining the genetic differences among the chickpea genotypes (Table 6).

The cluster analysis showed that the 39 accessions were divided into five clusters (Fig. 1). The first cluster included FLIP97-706C and FLIP03-77C. The second cluster included only FLIP09-148C. The third cluster included FLIP09-85C, FLIP09-90C, FLIP09-98C, FLIP09115C, FLIP09-337C and FLIP09-386C. The forth cluster included FLIP03-130C, FLIP09-214C, FLIP09-216C, FLIP09-218C, FLIP09-219C, ILC482, FLIP 82-150C, FLIP88-85C, FLIP93-93C, FLIP07-180C and FLIP0988C. The fifth cluster included FLIP06-158C, FLIP0720C, FLIP07-239C, FLIP07-280C, FLIP08-200C, FLIP09-149C, FLIP09-189C, FLIP09-191C and FLIP09192C.

\subsection{POPULATION STRUCTURE}

The marker segregation data was used for the population clustering, the STRUCTURE analysis separated the population into four cluster (Fig. 2). The 39 chickpea genotypes were grouped in to four subpopulations, as viewed in STRUCTURE analysis (Fig. 2).

Genotypes 39, 38, 20, 19, 18 and 37, respectively, were named as FLIP09-386C, FLIP09-337C, FLIP0998C, FLIP09-90C, FLIP09-85C and FLIP09-115C, respectively. Genotypes 31, 32, 33, 28, 30, 27, 29, 26 and 34 respectively with the letters ILC482, FLIP 82-150C, FLIP88-85C, FLIP09-216C, FLIP09-219C, FLIP09214C, FLIP09-218C, FLIP09 -194C and FLIP93-93C belonged to the second subpopulation. Genotypes 13, $11,12,14,16,6,17,15,8,5,7,9$ and 10 respectively with the names FLIP07-280C, FLIP07-239C, FLIP07-261C, FLIP08-46C, FLIP09-70C, FLIP07-20C, FLIP09-81C, FLIP08-200C, FLIP07-28C, FLIP07-19C, FLIP07-22C, FLIP07-31C and FLIP07-44C were in the third subpopulation and genotypes $23,3,24,25,22,2,1,4,35$, 36 and 21 respectively with the letters FLIP09-189C, FLIP03-130C, FLIP09-191C, FLIP09-192C, FLIP09149C, FLIP03-77C, FLIP97-706C, FLIP06-158C, FLIP07-180C, FLIP09 -88C and FLIP09-148C were also included in the fourth subpopulation (Figure 2). 


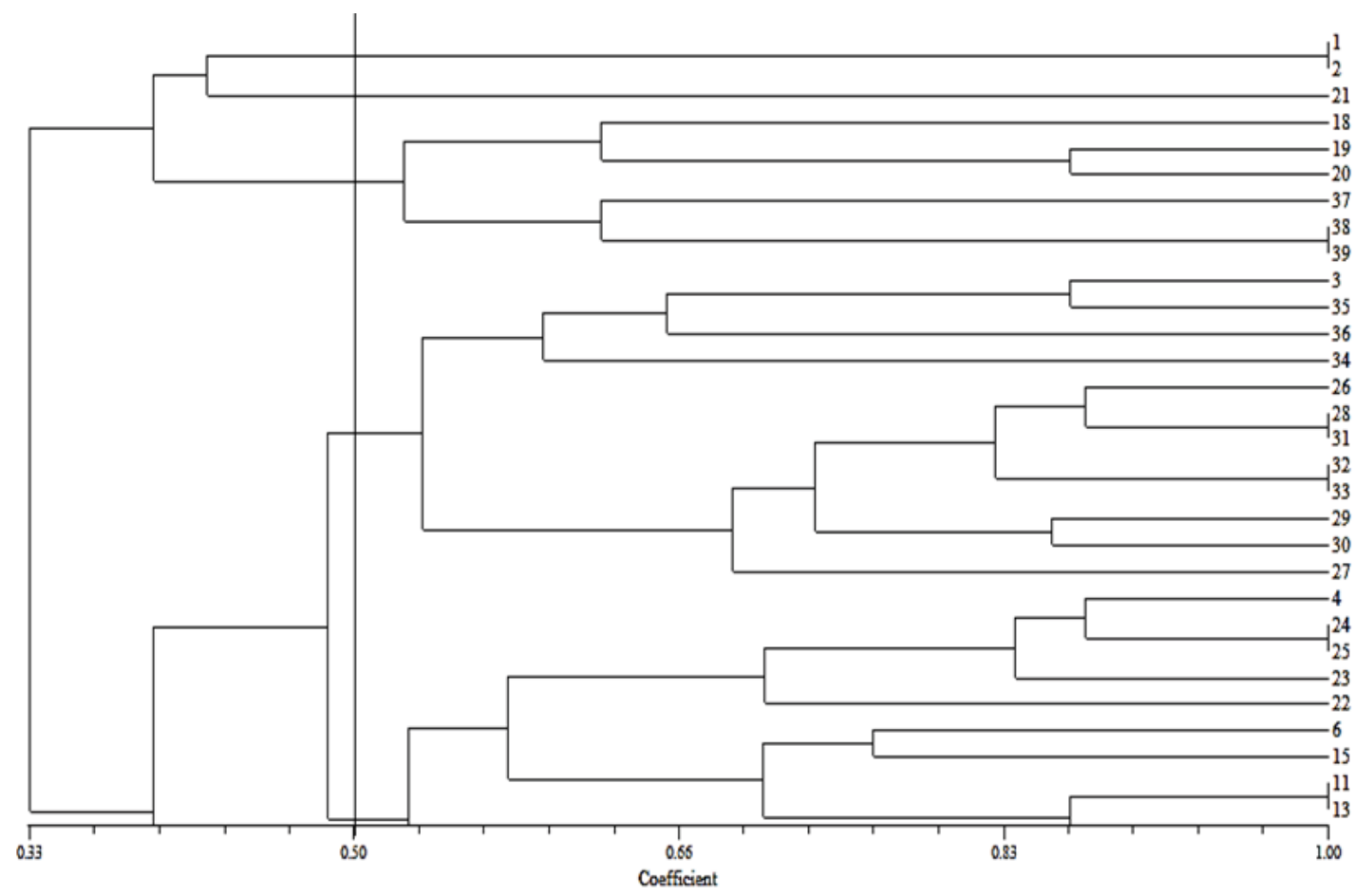

Figure 1: A dendrogram based on SSR markers of the 39 chickpea genotypes by UPGMA method

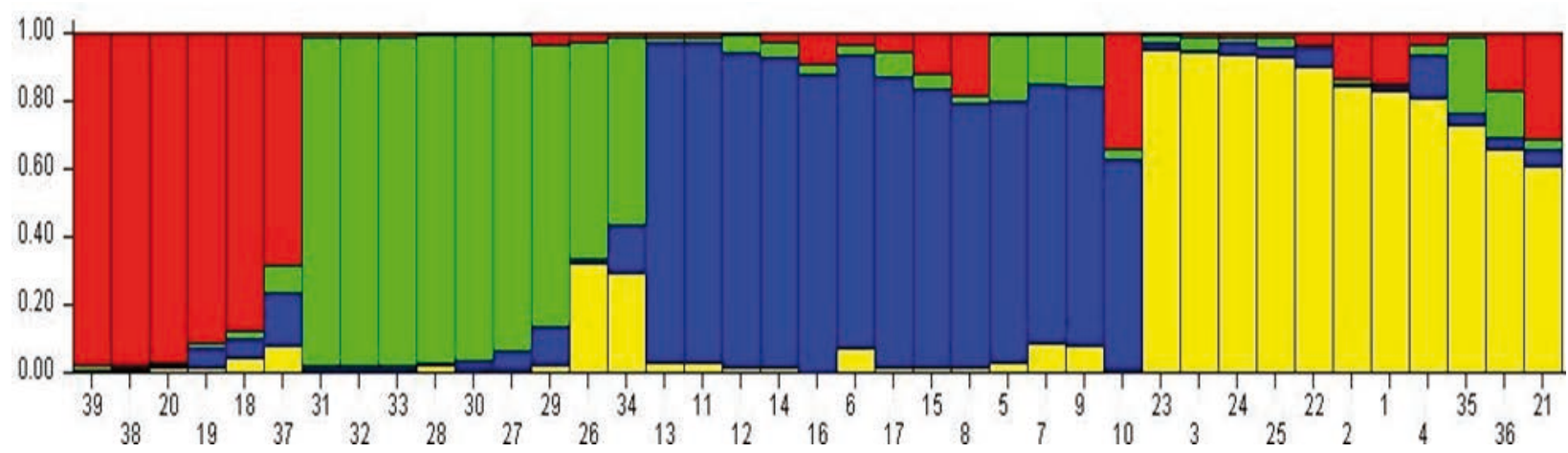

Figure 2: Genetic relatedness of 39 genotypes of chickpea with 10 SSR primer combinations as analyzed by the STRUCTURE program

\subsection{ASSOCIATION ANALYSIS}

The markers with minor allele frequency less than $5 \%$, remove so 21 marker loci retained for association analysis (Table 7). As in table 7 seen, AF016458 significantly associated with root fresh masst, root diameter, root volume density, root area, root length density, root area density, root length and root flavor. The 16549 marker was significantly associated to root fresh mass, root volume density, root area, root volume, root fine- ness and root area density. Significant associations were observed to the marker 19075 with root flavor. PsAS2 was significantly associated with root flavor, root volume density, root area, root volume, root fresh mass and root area density.

\section{DISCUSSION}

Several putative root traits contributing to drought 


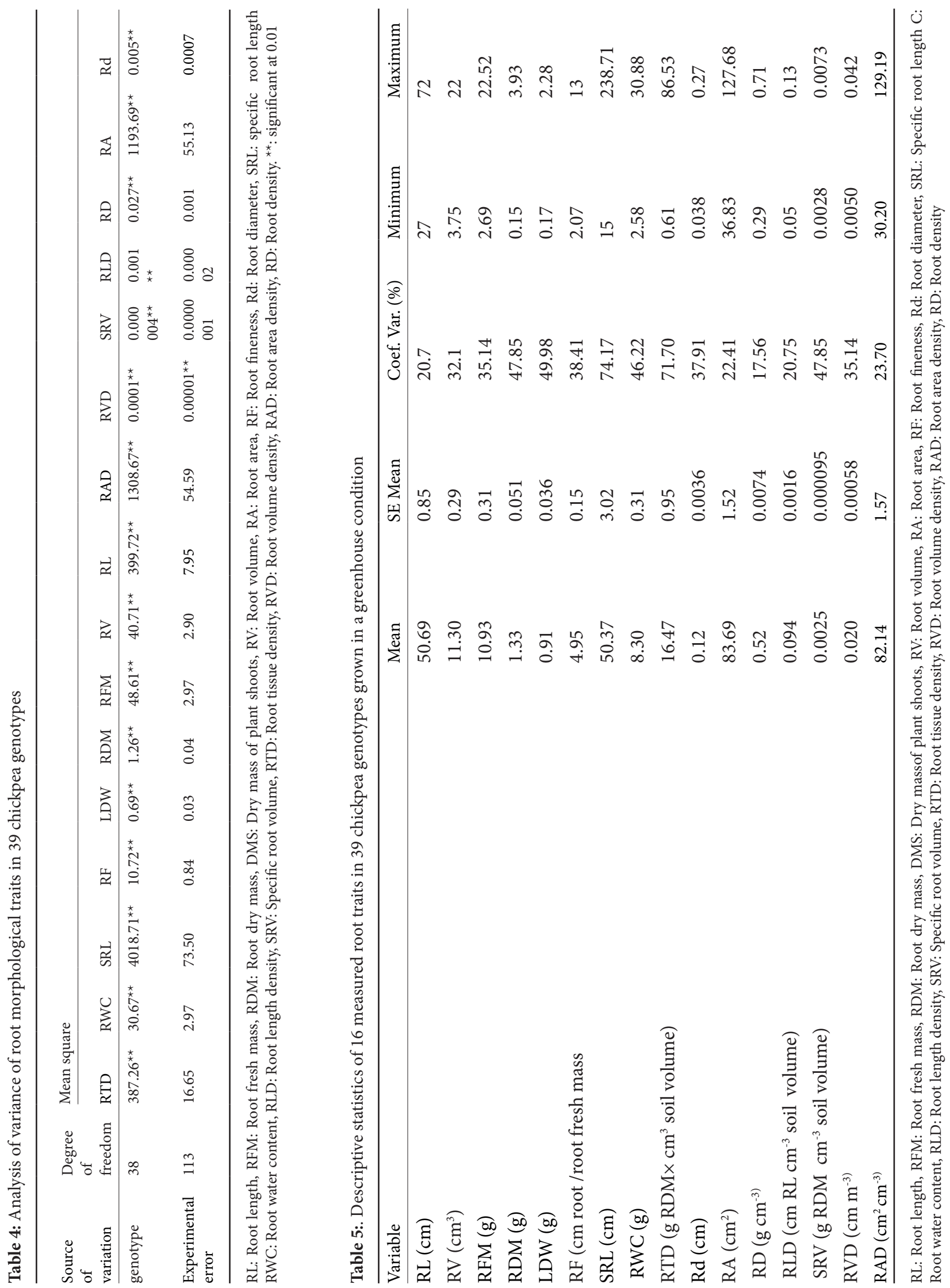


Table 6: The number and size range of bands produced by the SSR primers among the 39 chickpea genotypes

\begin{tabular}{lll}
\hline $\begin{array}{l}\text { Marker } \\
\text { name }\end{array}$ & $\begin{array}{l}\text { Number of } \\
\text { observed } \\
\text { alleles }\end{array}$ & $\begin{array}{l}\text { Polymorphism } \\
\text { information } \\
\text { content (PIC) }\end{array}$ \\
\hline 19075 & 3 & 0.57 \\
18363 & 2 & 0.47 \\
16549 & 3 & 0.66 \\
C24 & 2 & 0.38 \\
PsAS2 & 2 & 0.48 \\
PSAB60 & 2 & 0.48 \\
PD23 & 3 & 0.59 \\
PSAD147 & 3 & 0.66 \\
17605 & 3 & 0.65 \\
AF016458 & 3 & 0.54 \\
Mean & 2.6 & 0.55 \\
\hline
\end{tabular}

resistance in chickpea has been found (Benjamin and Nielsen, 2006; Fukai et al., 1995; Ali et al., 2005; Kashiwagi et al., 2008). Phenotypic selection for root traits is difficult because of the laborious, time-consuming and destructive methods involved in root studies (Gaur et al., 2008). An effort has been made in this study to identify the markers showed association with root traits in chickpea using a diverse set of genotypes. All of the measured root related traits differed significantly among genotypes $(p \leq 0.001)$ (Table 4$)$. The variation (Coef. Var ) in all root-related traits (17.56-74.17 \% (Table 5)) observed in the genotypes in the present study justifies its use for association analysis. Breseghello \& Sorrells (2006) suggested use of diverse genotypes for the purpose of association mapping.

FLIP09-192C had the highest root fresh mass, root dry mass, the average leaf dry mass, root diameter, the average specific root volume, root volume density and root area density and FLIP07-31C had the highest root

Table 7: Marker-trait associations with MLM and GLM models

\begin{tabular}{|c|c|c|c|c|c|}
\hline \multirow[b]{2}{*}{ Traits } & \multirow[b]{2}{*}{ Marker name } & \multirow{2}{*}{ No. of Associations } & \multicolumn{2}{|c|}{ P. value } & \multirow[b]{2}{*}{$\mathrm{R}^{2}(\%)$} \\
\hline & & & MLM & GLM & \\
\hline Root fresh mass & PsAS2 & 2 & 0.047 & 0.039 & 44.9 \\
\hline Root fresh mass & AF016458 & 3 & - & 0.042 & 44.1 \\
\hline Root fresh mass & 16549 & 3 & 0.021 & 0.038 & 45.2 \\
\hline Root diameter & AF016458 & 3 & 0.042 & 0.045 & 34.8 \\
\hline Root volume density & 16549 & 3 & 0.025 & 0.037 & 45 \\
\hline Root volume density & AF016458 & 3 & - & 0.048 & 42.2 \\
\hline Root volume density & PsAS2 & 2 & 0.047 & 0.039 & 44.8 \\
\hline Root flavor & AF016458 & 3 & 0.039 & 0.025 & 37.2 \\
\hline Root flavor & 16549 & 3 & 0.039 & 0.042 & 32.5 \\
\hline Root flavor & 19075 & 2 & 0.034 & 0.046 & 31.7 \\
\hline Root flavor & PsAS2 & 2 & - & 0.044 & 32 \\
\hline Root area & AF016458 & 3 & - & 0.038 & 40.1 \\
\hline Root area & PsAS2 & 2 & 0.046 & 0.016 & 49 \\
\hline Root area & 16549 & 3 & 0.027 & 0.014 & 49.9 \\
\hline Root length density & AF016458 & 3 & 0.038 & 0.029 & 31.7 \\
\hline Root volume & 16549 & 3 & 0.050 & 0.017 & 51.6 \\
\hline Root volume & PsAS2 & 2 & 0.029 & 0.019 & 50.9 \\
\hline Root area density & 16549 & 3 & 0.036 & 0.025 & 46.2 \\
\hline Root area density & AF016458 & 3 & 0.041 & 0.019 & 48.9 \\
\hline Root area density & PsAS2 & 2 & - & 0.026 & 45.9 \\
\hline Root length & AF016458 & 3 & 0.049 & 0.030 & 31.6 \\
\hline
\end{tabular}


volume, the average leaf dry mass, root water content, the average root area. Generally, tolerant genotypes have high root growth vigor and deeper soil root proliferation under drought stress, allowing them to extract water from all soil depths and maintain yield and $\mathrm{HI}$ (Maphosa et al., 2020). The marker segregation data grouped FLIP07-31C and FLIP09-192C in the third and fourth subpopulation respectively.

In this research, a total of 26 alleles with a mean of 2.6 alleles per locus were found. Also, the mean PIC value was 0.55 (Table 6). So that according to indicated genetic diversity among cultivated chickpea genotypes was lesser than the wild chickpea genotypes (Ghaffari et al., 2014 and Hajibarat et al., 2015) and the wild chickpea species showed greater PIC value and number of allele count per locus (Upadhyaya et al. (2008) and Ghaffari et al. (2014)).

The 39 genotypes used for association analysis were split in to four distinct subpopulations at $\mathrm{K}=4$ (Fig. 2). Genotypes in a subpopulation often have similar pedigrees (Table 1). The presence of subpopulations within a population can be due to reasons such as the different geographical origin of the genotypes, natural or human selection, or genetic drift (Flint-Garcia et al., 2003; Buckler \& Thornsberry, 2002).

In the present study, a total of 10 SSR markers have been used for genotyping the 39 chickpea The microsatellite markers showing association with root traits were detected using TASSEL software. A total of 21 markertrait association have been found in this study at $p<$ 0.05. The markers, PsAS2, AF016458, 16549 and 19075 on LG1, LG3, LG2, LG1 linkage group respectively was linked with root fresh mass root diameter, root volume density, root area, root length density, root area density, root length and root flavor.

Several QTLs controlling root traits have been reported (Kale et. al., 2015; Gaur et al., 2008; Varshney et al., 2014). Chandra et al. (2004) reported that a SSR marker, TAA 170, was associated with root mass and root length under drought stress in chickpea. Li et al. (2018) found that several SNPs from auxin-related genes were associated with yield and yield-related traits under drought condition. H6C-07 (on LG3) and H5G01 (on LG4) markers found that associated with QTLs for many drought-related traits (Hamwieh et al., 2013). Thudi et al. (2014b) discovered over 200 SSR, DArT, and SNP markers associated with drought-related traits. The most of highly expressed ESTs encoded proteins involved in cellular organization, protein metabolism, signal transduction, and transcription in the chickpea under drought stress (Jain \& Chattopadhyay, 2010). The role of hypothetical abscissic acid and stress ripening (ASR) protein NP_001351739.1 in mediating drought responses as a transcription factor were recognized in chickpea (Sachdeva et al., 2020). A "QTL-hotspot" containing quantitative trait loci (QTL) for several root and drought tolerance traits was transferred through marker assisted backcrossing into JG 11, a leading variety of chickpea (Cicer arietinum L.) in India from the donor parent ICC 4958. some introgression lines were identified that may be released as improved variety with enhanced drought tolerance (Varshney et al., 2013).

\section{CONCLUSIONS}

In conclusion, this study demonstrated the existence of genetic diversity exists in the current chickpea germplasm for root traits. The present study has helped in identification of significant marker-trait associations on LG1, LG2 and LG3. This shows that these chromosomes are potential candidate ones for emphasizing future studies. The research findings provide valuable information for marker-assisted selection improving root traits after validation for chickpea breeders.

\section{ACKNOWLEDGMENTS}

This study was supported by Ilam University. Chickpea accessions were obtained from Agricultural and Natural Resources Research and Education Center of Kurdistan, Sanandaj, Iran.

Conflict of interest: The authors declare that they have no conflict of interest.

Authors' Contributions: Zahra Shekari: Collection of experimental data. Zahra Tahmasebi: supervision of the study and writing of manuscript. Homayon Kanoni: review of the manuscript. Ali Asherf Mehrabi: molecular and statistical analysis.

\section{REFERENCES}

Ahmad, F., Gaur, P., \& Croser, J. (2005). Chickpea (Cicer arietinum L.). In 'Genetic resources, chromosome engineering and crop improvement-grain legumes'.(Eds R Singh, P Jauhar) pp. 185-214. https://doi.org/10.1201/9780203489284.ch7

Akhavan, S., Shabanpour, M., \& Esfahani, M. (2012). Soil compaction and texture effects on the growth of roots and shoots of wheat. Journal of Water and Soil, 26(3), 727-735. doi: 10.22067/JSW.V0I0.14941.

Beebe, S. E., Rojas-Pierce, M., Yan, X., Blair, M. W., Pedraza, F., Munoz, F., .. \& Lynch, J. P. (2006). Quantitative trait loci for root architecture traits correlated with phosphorus acquisition in common bean. Crop Science, 46(1), 413-423. https://doi.org/10.2135/cropsci2005.0226 
Benjamin, J. G., \& Nielsen, D. C. (2006). Water deficit effects on root distribution of soybean, field pea and chickpea. Field Crops Research, 97(2-3), 248-253. https://doi.org/10.1016/j. fcr.2005.10.005

Bradbury, P. J., Zhang, Z., Kroon, D. E., Casstevens, T. M., Ramdoss, Y., \& Buckler, E. S. (2007). TASSEL: software for association mapping of complex traits in diverse samples. Bioinformatics, 23(19), 2633 2635. https://doi.org/10.1093/ bioinformatics/btm 308

Breseghello, F., \& Sorrells, M. E. (2006). Association mapping of kernel size and milling quality in wheat (Triticum aestivum L.) cultivars. Genetics, 172(2), 1165-1177. https://doi. org/10.1534/genetics.105.044586

Buckler IV, E. S., \& Thornsberry, J. M. (2002). Plant molecular diversity and applications to genomics. Current Opinion in Plant Biology, 5(2), 107-111. https://doi.org/10.1016/ S1369-5266(02)00238-8

Chandra, S., Buhariwalla, H.K., Kashiwagi, J., Harikrishna, S., Rupa Sridevi, K., Chandra, S., Buhariwalla, H. K., Kashiwagi, J., \& Harikrishna, S. (2004). Identifying QTL-linked markers in marker-deficient crops. In 4th International Crop Science Congress. Markers, 2(38.1), 235.

Chen, Y., Ghanem, M. E., \& Siddique, K. H. (2017). Characterising root trait variability in chickpea (Cicer arietinum L.) germplasm. Journal of Experimental Botany, 68(8), 19871999. https://doi.org/10.1093/jxb/erw368

de Dorlodot, S., Forster, B., Pagès, L., Price, A., Tuberosa, R., \& Draye, X. (2007). Root system architecture: opportunities and constraints for genetic improvement of crops. Trends in Plant Science, 12(10), 474-481. https://doi.org/10.1016/j. tplants.2007.08.012

Doyle, J. J., \& Doyle, J. L. (1987). A rapid DNA isolation procedure for small quantities of fresh leaf tissue (No. RESEARCH).

Evanno, G., Regnaut, S., \& Goudet, J. (2005). Detecting the number of clusters of individuals using the software STRUCTURE: a simulation study. Molecular Ecology, 14(8), 2611-2620. Gaur, P.M., Krishnamurthy, L. and Kashiwagi, J. 2008. Improving drought-avoidance root traits in chickpea (Cicer arietinum L.)-current status of research at ICRISAT. Plant Production Science, 11(1), 3-11. https://doi.org/10.1111/j.1365-294X.2005.02553.x

Fukai, S., \& Hammer, G. L. (1995). Growth and yield response of barley and chickpea to water stress under three environments in southeast Queensland. II. Root growth and soil water extraction pattern. Australian Journal of Agricultural Research, 46(1), 35-48. https://doi.org/10.1071/ AR9950035.

Gaur PM, Krishnamurthy L, Kashiwagi J. (2008). Improving drought-avoidance root traits in chickpea (Cicer arietinum L.)-current status of research at ICRISAT. Plant Production Science, 11(1), 3-11. https://doi.org/10.1626/ pps.11.3

Ghaffari, P., Talebi, R., \& Keshavarzi, F. (2014). Genetic diversity and geographical differentiation of Iranian landrace, cultivars, and exotic chickpea lines as revealed by morphological and microsatellite markers. Physiology and Molecular Biology of Plants, 20(2), 225-233. https://doi. org/10.1007/s12298-014-0223-9

Ghanem, M. E., Hichri, I., Smigocki, A. C., Albacete, A., Fau- connier, M. L., Diatloff, E., .. \& Pérez-Alfocea, F. (2011). Root-targeted biotechnology to mediate hormonal signalling and improve crop stress tolerance. Plant Cell Reports, 30(5), 807-823. https://doi.org/10.1007/s00299-0111005-2

Hajabbasi, M. A. (2001). Tillage effects on soil compactness and wheat root morphology. Journal of Agricultural Science and Technology, 3(1), 67-77.

Hajibarat, Z., Saidi, A., Hajibarat, Z., \& Talebi, R. (2015). Characterization of genetic diversity in chickpea using SSR markers, start codon targeted polymorphism (SCoT) and conserved DNA-derived polymorphism (CDDP). Physiology and Molecular Biology of Plants, 21(3), 365-373. https:// doi.org/10.1007/s12298-015-0306-2

Hamwieh, A., Imtiaz, M., \& Malhotra, R. S. (2013). Multienvironment QTL analyses for drought-related traits in a recombinant inbred population of chickpea (Cicer arientinum L.). Theoretical and Applied Genetics, 126(4), 10251038. https://doi.org/10.1007/s00122-012-2034-0

Hasanabadi, T., Ardakani, M. R., Rejali, F., Paknejad, F., Eftekhari, S. A., \& Zargari, K. (2010). Response of barley root characters to co-inoculation with Azospirillum lipoferum and Pseudomonas flouresence under different levels of nitrogen. American-Eurasian Journal of Agricultural and Environmental Science, 9(2), 156-162. ISSN : 1818-6769

Jaganathan, D., Thudi, M., Kale, S., Azam, S., Roorkiwal, M. \& Gaur, P.M., et al. (2015). Genotyping-by-sequencing based intra-specific genetic map refines a "QTL hotspot" region for drought tolerance in chickpea. Molecular Genetics and Genomics, 290(2), 559-71. https://doi.org/10.1007/ s00438-014-0932-3

Jain, D., \& Chattopadhyay, D. (2010). Analysis of gene expression in response to water deficit of chickpea (Cicer arietinum L.) varieties differing in drought tolerance. $B M C$ Plant Biology, 10(1), 1-14. https://doi.org/10.1186/14712229-10-24

Jha, U. C., Jha, R., Bohra, A., Parida, S. K., Kole, P. C., Thakro, V., .. \& Singh, N. P. (2018). Population structure and association analysis of heat stress relevant traits in chickpea (Cicer arietinum L.). 3 Biotech, 8(1), 43. https://doi. org/10.1007/s13205-017-1057-2

Kale, S.M., Jaganathan, D., Ruperao, P., Chen, C., Punna, R., Kudapa, H., (2015). Prioritization of candidate genes in "QTL-hotspot" region for drought tolerance in chickpea (Cicer arietinum L.). Scientific Reports, 5(1),15296. https:// doi.org/10.1038/srep15296

Kashiwagi, J., Krishnamurthy, L., Crouch, J. H., \& Serraj, R. (2006). Variability of root length density and its contributions to seed yield in chickpea (Cicer arietinum L.) under terminal drought stress. Field Crops Research, 95(2-3), 171181. https://doi.org/10.1016/j.fcr.2005.02.012

Kashiwagi, J., Krishnamurthy, L., Gaur, P. M., Chandra, S., \& Upadhyaya, H. D. (2008). Estimation of gene effects of the drought avoidance root characteristics in chickpea (C. arietinum L.). Field Crops Research, 105(1-2), 64-69. https:// doi.org/10.1016/j.fcr.2007.07.007

Keneni, G., Bekele, E., Imtiaz, M., Dagne, K., Getu, E., \& Assefa, F. (2012). Genetic diversity and population structure of Ethiopian chickpea (Cicer arietinum L.) germplasm ac- 
cessions from different geographical origins as revealed by microsatellite markers. Plant Molecular Biology Reporter, 30(3), 654-665. https://doi.org/10.1007/s11105-0110374-6

Kirkegaard, J. A., Lilley, J. M., Howe, G. N., \& Graham, J. M. (2007). Impact of subsoil water use on wheat yield. Australian Journal of Agricultural Research, 58(4), 303-315. https://doi.org/10.1071/AR06285

Li, Y., Ruperao, P., Batley, J., Edwards, D., Khan, T., Colmer, T. D., .. \& Sutton, T. (2018). Investigating drought tolerance in chickpea using genome-wide association mapping and genomic selection based on whole-genome resequencing data. Frontiers in Plant Science, 9, 190. https:/doi. org/10.3389/fpls.2018.00190

Lovelli, S., Perniola, M., Di Tommaso, T., Bochicchio, R., \& Amato, M. (2012). Specific root length and diameter of hydroponically-grown tomato plants under salinity. Journal of Agronomy, 11(4), 11. https://doi.org/10.3923/ ja.2012.101.106

Ludlow, M. M., \& Muchow, R. C. (1990). A critical evaluation of traits for improving crop yields in water-limited environments. Advances in Agronomy, 43, 107-153. https://doi. org/10.1016/S0065-2113(08)60477-0

Mahanta, D., Rai, R. K., Mishra, S. D., Raja, A., Purakayastha, T. J., \& Varghese, E. (2014). Influence of phosphorus and biofertilizers on soybean and wheat root growth and properties. Field Crops Research, 166, 1-9. https://doi. org/10.1016/j.fcr.2014.06.016

Malamy, J.E., 2005. Intrinsic and environmental response pathways that regulate root system architecture. Plant, Cell \& Environment, 28(1), 67-77. https://doi.org/10.1111/ j.1365-3040.2005.01306.x

Maphosa, L., Richards, M. F., Norton, S. L., \& Nguyen, G. N. (2020). Breeding for abiotic stress adaptation in chickpea (Cicer arietinum L.): A comprehensive review. Crop Breeding, Genetics and Genomics, 4(3). https://doi.org/10.20900/ cbgg 20200015

Mugabe, D., Coyne, C. J., Piaskowski, J., Zheng, P., Ma, Y., Landry, E., ... \& Abbo, S. (2019). Quantitative trait loci for cold tolerance in chickpea. Crop Science, 59(2), 573-582. https:// doi.org/10.2135/cropsci2018.08.0504

Nei, M. (1973). Analysis of gene diversity in subdivided populations. Proceedings of the National Academy of Sciences, 70(12), 3321-3323. https://doi.org/10.1073/ pnas.70.12.3321

Passioura, J. (2006). Increasing crop productivity when water is scarce-from breeding to field management. Agricultural Water Management, 80(1-3), 176-196. https://doi. org/10.1016/j.agwat.2005.07.012

Pritchard, J. K., Stephens, M., \& Donnelly, P. (2000). Inference of population structure using multilocus genotype data. Genetics, 155(2), 945-959. https://doi.org/10.1093/ genetics/155.2.945

Ramamoorthy, P., Lakshmanan, K., Upadhyaya, H. D., Vadez, V., \& Varshney, R. K. (2017). Root traits confer grain yield advantages under terminal drought in chickpea (Cicer arietinum L.). Field crops research, 201, 146-161. https://doi. org/10.1016/j.fcr.2016.11.004

Rohlf, F.J. (2000). NTSYS-pc: numerical taxonomy and multi- variate analysis system, version 2.1. New York: Exeter Software. https://doi.org/10.1016/j.fcr.2016.11.004

Sachdeva, S., Bharadwaj, C., Singh, R. K., Jain, P. K., Patil, B. S., Roorkiwal, M., \& Varshney, R. (2020). Characterization of ASR gene and its role in drought tolerance in chickpea (Cicer arietinum L.). PloS One, 15(7), e0234550. https://doi. org/10.1371/journal.pone.0234550

Schenk, M. K., \& Barber, S. A. (1979). Root characteristics of corn genotypes as related to $\mathrm{p}$ uptake 1. Agronomy Journal, 71(6), 921-924. https://doi.org/10.2134/agronj1979.00 021962007100060006x

Sefera, T., Abebie, B., Gaur, P. M., Assefa, K., \& Varshney, R. K. (2011). Characterisation and genetic diversity analysis of selected chickpea cultivars of nine countries using simple sequence repeat (SSR) markers. Crop and Pasture Science, 62(2), 177-187. https://doi.org/10.1071/CP10165

Thudi, M., Gaur, P. M., Krishnamurthy, L., Mir, R. R., Kudapa, H., Fikre, A., .. \& Varshney, R. K. (2014a). Genomics-assisted breeding for drought tolerance in chickpea. Functional Plant Biology, 41(11), 1178-1190. https://doi.org/10.1071/ FP13318

Thudi, M., Upadhyaya, H. D., Rathore, A., Gaur, P. M., Krishnamurthy, L., Roorkiwal, M., .. \& Varshney, R. K. (2014b). Genetic dissection of drought and heat tolerance in chickpea through genome-wide and candidate gene-based association mapping approaches. Plos One, 9(5), e96758. https:// doi.org/10.1371/journal.pone.0096758

Tuberosa, R., \& Salvi, S. (2006). Genomics-based approaches to improve drought tolerance of crops. Trends in Plant Science, 11(8), 405-412. https://doi.org/10.1016/j. tplants.2006.06.003

Tuberosa, R., Salvi, S., Sanguineti, M. C., Landi, P., Maccaferri, M., \& Conti, S. (2002). Mapping QTLs regulating morphophysiological traits and yield: Case studies, shortcomings and perspectives in drought-stressed maize. Annals of Botany, 89(7), 941-963. https://doi.org/10.1093/aob/mcf134

Upadhyaya, H. D., Dwivedi, S. L., Baum, M., Varshney, R. K., Udupa, S. M., Gowda, C. L., .. \& Singh, S. (2008). Genetic structure, diversity, and allelic richness in composite collection and reference set in chickpea (Cicer arietinum L.). BMC Plant Biology, 8(1), 1-12. https://doi. org/10.1186/1471-2229-8-106

Varshney, R. K., Gaur, P. M., Chamarthi, S. K., Krishnamurthy, L., Tripathi, S., Kashiwagi, J., .. \& Jaganathan, D. (2013). Fast-track introgression of "QTL-hotspot" for root traits and other drought tolerance traits in JG 11, an elite and leading variety of chickpea. The Plant Genome, 6(3). https://doi.org/10.3835/plantgenome2013.07.0022

Varshney, R. K., Thudi, M., Nayak, S. N., Gaur, P. M., Kashiwagi, J., Krishnamurthy, L., .. \& Viswanatha, K. P. (2014). Genetic dissection of drought tolerance in chickpea (Cicer arietinum L.). Theoretical and Applied Genetics, 127(2), 445462. https://doi.org/10.1007/s00122-013-2230-6

Wasson, A. P., Rebetzke, G. J., Kirkegaard, J. A., Christopher, J., Richards, R. A., \& Watt, M. (2014). Soil coring at multiple field environments can directly quantify variation in deep root traits to select wheat genotypes for breeding. Journal of Experimental Botany, 65(21), 6231-6249. https://doi. org/10.1093/jxb/eru250 
Yang, T., Fang, L., Zhang, X., Hu, J., Bao, S., Hao, J., .. \& Zong, X. (2015). High-throughput development of SSR markers from pea (Pisum sativum L.) based on next generation sequencing of a purified Chinese commercial variety. PLoS One, 10(10), e0139775. https://doi.org/10.1371/journal. pone. 0139775

Yusuf Ali, M., Johansen, C., Krishnamurthy, L., \& Hamid, A. (2005). Genotypic variation in root systems of chick- pea (Cicer arietinum L.) across environments. Journal of Agronomy and Crop Science, 191(6), 464-472. https://doi. org/10.1111/j.1439-037X.2005.00177.x

Zaman-Allah, M., Jenkinson, D. M., \& Vadez, V. (2011). A conservative pattern of water use, rather than deep or profuse rooting, is critical for the terminal drought tolerance of chickpea. Journal of Experimental Botany, 62(12), 42394252. https://doi.org/10.1093/jxb/err139 